\title{
Pengaruh Disiplin Kerja dan Motivasi Kerja Terhadap Kinerja Karyawan (Studi Kasus pada PT. Permodalan Nasional Madani (Persero) Cabang Padang)
}

\author{
Frans Zella, Maria Magdalena \\ Sekolah Tinggi Ilmu Ekonomi KBP
}

\begin{abstract}
The highest employee performance will make employer more loyal to the organization, and will get more motivated to work and working on happy feeling. The one important think is working with satisfysense would be enlarging chance to get high productivity and performance as well. For creating employee performance more effectively and efficiently is not an easy, not only to create high discipline but also motivation factor is affected. Therefore, company can drive an employee to have high motivation to get the company's objective.This paper, in critically examines the relation of discipline and work motivation toward employee performance of PT. Permodalan Nasional Madani (Persero) Padang in quantitative approach and documents tracking as well. Meanwhile, the question of this research is what is the relationship between discipline and employe performance? Do they have a correlation?, and in the same question is involved to examine the motivation factor into the their working performance in term of PT. Permodalan Nasional Madani. This research had shown that discipline is positively and significantly affected toward employee performance. However, working motivation is not positively and significantly affected toward employee performance of PT. PNM Padang.
\end{abstract}

Keywords: Influence, working discipline, working motivation, employee performance, PT.PNM

\section{PENDAHULUAN}

\section{Latar Belakang Masalah}

Sumber daya manusia manusia memiliki posisi sangat strategis dalam organisasi, artinya unsur manusia memegang peranan penting dalam melakukan aktivitas untuk mencapai tujuan. Untuk itulah eksistensi sumber daya manusia dalam organisasi sangat kuat (Ambar Teguh Sulistiyani dan Rosidah, 2003) dalam (Pratiwi, 2014).

Manusia selalu berperan aktif dan dominan dalam setiap kegiatan organisasi karena manusia menjadi perencana, pelaku, dan penentu terwujudnya tujuan organisasi. Tujuan tidak mungkin terwujud tanpa peran aktif karyawan meskipun alat-alat yang dimiliki perusahaan begitu canggihnya (Hasibuan,2003) dalam (Pratiwi, 2014).

Oleh karena itu keberhasilan suatu perusahaan tidak hanya tergantung dengan teknologi perusahaan melainkan juga tergantung pada aspek sumber daya manusia yang dimiliki oleh perusahaan. Sehingga suatu perusahaan membutuhkan sumber daya manusia yang potensial, baik pemimpin maupun karyawan dapat memberikan kontribusi yang baik dan melaksanakan tugas 
dengan optimal untuk mencapai tujuan perusahaan. Karena semua kegiatan perusahaan akan melibatkan tindakan sumber daya manusia yang ada didalamnya.

Motivasi kerja merupakan hal yang penting dalam meningkatkan suatu efektivitas kerja. Karena orang yang mempunyai motivasi kerja yang tinggi akan berusaha dengan sekuat tenaga agar pekerjaanya dapat berhasil dengan sebaik baiknya. Motivasi kerja mempersoalkan bagaimana caranya mendorong gairah kerja bawahan, agar mereka mau bekerja keras dengan memberikan semua kemampuan dan keterampilannya untuk mewujudkan tujuan perusahaan (Raditya Priyo dkk, 2014: 1) dalam (Riyadi, 2016).

Menurut Budi Setiyawan dan Waridin (2006) dalam (Riyadi, 2016) disiplin sebagai keadaan ideal dalam mendukung pelaksanaan tugas sesuai aturan dalam rangka mendukung optimalisasi kerja. Untuk itu disiplin harus ditumbuh kembangkan agar tumbuh pula ketertiban dan evisiensi. Tanpa adanya disiplin yang baik, jangan harap akan dapat diwujudkan adanya sosok pemimpin atau karyawan ideal sebagaimana yang diharapkan oleh masyarakat dan perusahaan. Menurut Budi Setiyawan dan Waridin (2006) dalam (Reza, 2010) disiplin kerja karyawan bagian dari faktor kinerja. Hasil penelitiannya menunjukan bahwa disiplin kerja memiliki pengaruh positif terhadap kinerja kerja karyawan.

Dalam hal ini PT.Permodalan Nasional Madani atau lebih disingkat PT.PNM merupakan Badan Usaha Milik negara yang bergerak dibidang jasa keuangan (Non Bank) yang didirikan oleh pemerintah guna membantu dan membina Usaha Mikro Kecil Menengah
(UMKM) melalui kantor unit ULaMM (Unit Layanan Modal Mikro). PT.PNM (Persero) memiliki visi untuk menjadi lembaga pembiayaan yang terkemuka dalam meningkatkan nilai tambah secara berkelanjutan bagi Usaha Mikro Kecil Menengah (UMKM) yang berlandaskan "Good Corporate Governance”, oleh karena itu sudah seharusnya karyawan memiliki disiplin kerja dan motivasi kerja yang tinggi untuk mewujudkan misi dan tujuan yang telah ditetapkan.

\section{Rumusan Masalah}

Berdasarkan latar belakang masalah diatas, maka dapat dirumuskan permasalahan yang dihadapi sebagai berikut:

1. Apakah disiplin kerja dapat mempengaruhi kinerja karyawan terhadap PT.PNM (Persero) Cabang Padang.

2. Apakah motivasi kerja dapat mempengaruhi kinerja karyawan terhadap PT.PNM (Persero) Cabang Padang.

\section{Tujuan Penelitian}

Tujuan berperan penting dalam suatu penelitian sehingga dengan tujuan penelitian akan dapat bekerja secara terarah. Berdasarkan rumusan masalah yang diatas, maka tujuan penelitian ini adalah sebagai berikut adapun tujuan dari penelitian ini adalah :

1. Untuk mengetahui apakah disiplin kerja berpengaruh terhadap kinerja karyawan PT.PNM (Persero) Cabang Padang.

2. Untuk mengetahui apakah motivasi kerja berpengaruh terhadap kinerja karyawan PT.PNM (Persero) Cabang Padang.

3. Untuk mengetahui apakah disiplin dan motivasi kerja simultan terhadap kinerja karyawan 
PT.PNM (Persero) Cabang

Padang.

\section{Kerangka Konseptual}

Dari perumusan masalah dan tinjauan teori tersebut diatas dapat disebut kerangka sebagai berikut:

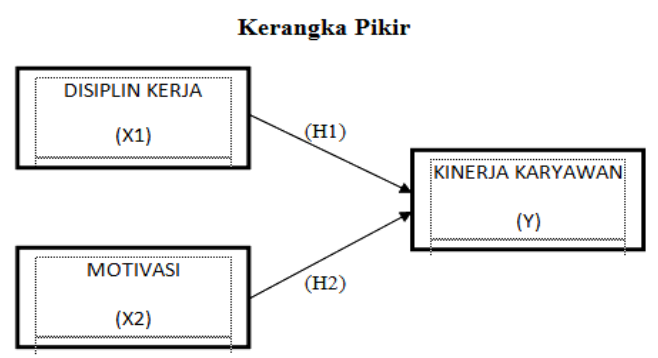

Sumber: (Sundari, 2014)

\section{Definisi Operasional Variabel Variabel Dependen}

Variabel dependen adalah variabel yang nilainya dipengaruhi oleh variabel independen. Variabel dependen adalah variabel yang menjadi pusat perhatian peneliti (Augusty Ferdinand, 2006). Dalam penelitian ini yang menjadi variabel dependen adalah : Kinerja Karyawan (Y).

Variabel Independen

Variabel independen yang dilambangkan dengan (X) adalah variabel yang mempengaruhi variabel dependen, baik yang pengaruhnya positif maupun yang pengaruhnya negatif (Augusty Ferdinand, 2006) dalam (Sanjaya, 2015). Dalam penelitian ini yang menjadi variabel independen adalah:
a. Disiplin Kerja (X1)

b. Motivasi Kerja (X2)

\section{Teknik Analisis Data}

Uji Validitas

Ujii Validitas digunakan untuk mengukur sah atau tidaknya suatu kuesioner. Suatu kuesioner dinyatakan valid jika pertanyaan pada kuesioner mampu mengungkapkan sesuatu yang akan diukur untuk kuesioner tersebut (Ghozali, 2006) dalam (Prihantoro, 2012).

\section{Uji Reliabilitas}

Metode yang akan digunakan untuk melakukan uji validitas adalah dengan melakukan korelasi antar skor butir pertanyaan dengan total skor konstruk atau variabel. Sedangkan untuk uji reliabilitas yang akan digunakan dalam penelitian ini, adalah dengan menggunakan fasilitas SPSS, yakni dengan uji statistik Cronbach Alpha. Suatu konstruk atau variabel dinyatakan reliabel jika nilai cronbach alpha $>0.60$. Nunnally (dikutip oleh Ghozali, 2006) dalam (Tri, Staff, Stie, \& Salatiga, 2010).

\section{Uji Tingakat Capaian Responden} (TCR)

Uji Tingakat Capaian Responden (TCR) digunakan untuk menghitung nilai Tingkat Capaian Responden (TCR) masing- masing kategori dari data deskriptif variabel. Rumus yang digunakan yaitu (Ridwan,2008:89) dalam (Usrin, Mutiara, \& Yusad, 2012)

$$
\mathrm{TCR}=\frac{R s}{n} \times 100 \%
$$

Keterangan:

TCR $=$ Tinggkat Capaian Responden

Rs = Rata- rata skor jawaban responden

$\mathrm{n} \quad=$ Nilai skor jawaban

Kriteria interpretasi skor untuk Tingkat Capaian Responden (TCR) adalah sebagai berikut: 
Tabel. 3.2 Rentang Skala TCR

\begin{tabular}{cl}
\hline Angka & \multicolumn{1}{c}{ Keterangan } \\
\hline $00 \%-20 \%$ & Sangat Tidak Baik \\
$21 \%-40 \%$ & Tidak Baik \\
$41 \%-60 \%$ & Kurang Baik \\
$61 \%-80 \%$ & Baik \\
$81 \%-100 \%$ & Sangat Baik
\end{tabular}

\section{Uji Asumsi Klasik}

\section{Uji Normalitas}

Uji normalitas bertujuan untuk menguji apakah dalam model regresi variabel pengganggu atau residual memiliki distribusi normal. Seperti diketahui bahwa uji $t$ dan $F$ mengasumsikan bahwa nilai residual mengikuti distribusi normal. Ada dua cara untuk mendeteksi apakah residual berdistribusi normal atau tidak yaitu dengan analisis grafik dan uji statistik (Ghozali, 2006).

\section{Uji Multikolinieritas}

Uji multikolinieritas bertujuan untuk menguji apakah modelregresi ditemukan adanya korelasi antar variabel bebas (independen). Jika ditemukan adanya multikolinieritas, maka koefisien regresi variabel tidak tentu dan kesalahan menjadi tidak terhingga (Ghozali, 2006) dalam (Prihantoro, 2012) . Salah satu metode untuk mendiagnosa adanya multicollinearity adalah denganmenganalisis nilai tolerance dan lawannya variance inflation factor (VIF).

Tolerance mengukur variabilitas variabel independen yang terpilih yang tidak dijelaskan oleh variabel independen lainnya. Nilai tolerance yang rendah sama dengan nilai VIF tinggi, karena VIF $=1 /$ Tolerance. Nilai cutoff yang dipakai untuk menunjukkan adanya multikolinearitas adalah nilai tolerance kurang dari 0,1 atau sama dengan nilai VIF lebih dari 10 (Ghozali, 2006 ).

\section{Uji Heteroskedastisitas}

Tujuan dari pengujian ini adalah untuk menguji apakah dalam model regresi terjadi ketidaksamaan variance dari residual satu pengamatan ke pengamatan lainnya. Model regresi yang baik adalah yang homoskesdastisitas, yakni variance dari residual satu pengamatan ke pengamatan lain bersifat tetap (Ghozali, 2006).

\section{Analisis Regresi Berganda}

Analisis regresi berganda untuk mengetahui apakah variabel independen berpengaruh atau tidak terhadap variabel dependen, maka dapat dilihat dari taraf signifikansinya dengan standar signifikansi 5\%. Apabila tingkat signifikansi yang diperoleh dari hasil lebih besar dari 5\% maka hipotesis ditolak, sebaliknya jika hasil uji hipotesis berada diantara 0-5\% maka hipotesis diterima. Analisis regresi berganda merupakan untuk mengetahui hubungan antara variabel independen dan variabel dependen. Persamaan regresi berganda adalah :

$$
\begin{aligned}
\mathrm{Y} & =\alpha+\beta 1 \mathrm{X} 1+\beta 2 \mathrm{X} 2+\mathrm{e} \\
\mathrm{Y} & =\text { Kinerja Karyawan } \\
\mathrm{X} 1 & =\text { Disiplin Kerja } \\
\mathrm{X} 2 & =\text { Motivasi Kerja } \\
\alpha & =\text { Koefisien Konstanta } \\
\beta 1 & =\text { Koefisien regresi untuk } \\
& \text { Disiplin Kerja } \\
\beta 2 & =\text { Koefisien untuk Motivasi Kerja } \\
\mathrm{e} & =\text { Standar error }
\end{aligned}
$$




\section{Hipotesis}

Uji F

Pengujian pengaruh variabel independen secara bersama- sama (simultan) terhadap perubahan nilai variabel dependen, dilakukan melalui pengujian terhadap besarnya perubahan nilai variabel dependen yang dapat dijelaskan oleh perubahan nilai semua variabel independen, untuk itu perlu dilakukan uji $F$. Uji $F$ atau ANOVA dilakukan dengan membandingkan tingkat signifikasi yang ditetapkan untuk penelitian dengan probability value dari hasil penelitian (Ghozali, 2006).

Uji T

Pengujian ini digunakan untuk menentukan apakah dua sampel tidak berhubungan, memiliki rata- rata yang berbeda. Uji t dilakukan dengan cara membandingkan perbedaan antara nilai dua nilai rata- rata dengan standar error dari perbedaan rata- rata dua sampel (Ghozali, 2006).

Profil Responden Karakteristik Responden

\begin{tabular}{|c|c|c|}
\hline Keterangan & Jumlah & Persentase \\
\hline \multicolumn{3}{|c|}{ Berdasarkan Jenis kelamin } \\
\hline 1. Laki-laki & $\begin{array}{ll}32 & \\
& \text { ora } \\
& \text { ng }\end{array}$ & $55.2 \%$ \\
\hline 2. Perempuan & $\begin{array}{l}26 \\
\quad \text { ora } \\
\text { ng }\end{array}$ & $44.8 \%$ \\
\hline
\end{tabular}

Berdasarkan Umur

1. 21-30 tahun 30

$51.7 \%$

2. $31-40$ tahun 28

$48.3 \%$

Berdasarkan Masa Kerja
1. 1-5 tahun 46
$79.3 \%$
2. 11-5 tahun 6
$10.3 \%$

Uji Koefisien Determinasi ( $\mathbf{R}^{2}$ )

Multikolnieritas terjadi apabila nilai $\mathrm{R}^{2}$ yang dihasilkan oleh suatu model regresi empiris sangat tinggi, tetapi secara individual variabelvariabel independen banyak yang tidak signifikan mempengaruhi variabel dependen (Ghozali, 2006).

\section{HASIL DAN PEMBAHASAN}

Gambaran Umum Perusahaan

PT. Permodalan Nasional Madani (Persero) didirikan pada pada 1 Juni 1999, sebagai BUMN yang mengemban tugas khusus memberdayakan usaha Mikro, PT. Permodalan Nasional Madani (Persero), atau "PNM", didirikan sebagai pelaksanaan dari Tap XVI MPR/1998 dengan modal dasar $\mathrm{Rp} 1,2$ triliun dan modal disetor Rp300 miliar.
3. $15-20$ tahun 6
$10.3 \%$

Pendidikan Terakhir

1.SMA/SMK $6 \quad 10.3 \%$

2. DIII $12 \quad 20.7 \%$

3. S1 $\quad 40 \quad 69 \%$

\section{Teknik Analisis Data \\ Uji Validitas \\ Uji Validitas Variabel Disiplin \\ Kerja (X1)}




\begin{tabular}{cccc}
\hline & $\begin{array}{c}\text { Corrected Item- } \\
\text { Total Correlation }\end{array}$ & Standar Pengukuran & Keterangan \\
\hline DK1 & 0,737 & 0,30 & Valid \\
DK2 & 0,642 & 0,30 & Valid \\
DK3 & 0,661 & 0,30 & Valid \\
DK4 & 0,675 & 0,30 & Valid \\
DK5 & 0,316 & 0,30 & Valid \\
DK6 & 0,726 & 0,30 & Valid \\
DK7 & 0,616 & 0,30 & Valid \\
\hline
\end{tabular}

Sumber : Data SPSS 17 (Data diolah tahun 2018)

Berdasarkan hasil dari perhitungan uji validitas variabel X1 (Disiplin Kerja) terhadap 58 responden, didapatkan bahwa semua butir pernyataan dinyatakan valid. Hal ini ditunjukkan dengan nilai Corrected Item-Total Correlation yang lebih besar dari 0,30, sehingga dapat dilakukan untuk penelitian lebih lanjut.

Uji Validitas Variabel Motivasi Kerja (X2)

\begin{tabular}{cccc}
\hline & $\begin{array}{c}\text { Corrected Item- } \\
\text { Total Correlation }\end{array}$ & Standar Pengukuran & Keterangan \\
\hline Mk1 & 0.687 & 0,30 & Valid \\
Mk2 & 0.312 & 0,30 & Valid \\
Mk4 & 0.680 & 0,30 & Valid \\
Mk5 & 0.352 & 0,30 & Valid \\
Mk6 & 0.615 & 0,30 & Valid \\
Mk7 & 0.687 & 0,30 & Valid \\
\hline
\end{tabular}

Sumber : Data SPSS 17 (Data diolah tahun 2018) 
Berdasarkan hasil dari perhitungan uji validitas variabel X2 (Motivasi Kerja) terhadap 58 responden, didapatkan bahwa semua butir pernyataan dinyatakan valid. Hal ini ditunjukkan dengan nilai Corrected Item-Total Correlation yang lebih besar dari 0,30, sehingga dapat dilakukan untuk penelitian lebih lanjut.

Uji Validitas Variabel Kinerja karyawan (Y)

\begin{tabular}{cccc}
\hline & $\begin{array}{c}\text { Corrected Item- } \\
\text { Total Correlation }\end{array}$ & Standar Pengukuran & Keterangan \\
\hline kk1 & 0,832 & 0,30 & Valid \\
kk2 & 0,758 & 0,30 & Valid \\
kk3 & 0,837 & 0,30 & Valid \\
kk4 & 0,700 & 0,30 & Valid \\
kk5 & 0,674 & 0,30 & Valid \\
kk6 & 0,854 & 0,30 & Valid \\
\hline
\end{tabular}

Sumber : Data SPSS 17 (Data diolah tahun 2018)

Berdasarkan hasil dari perhitungan uji validitas variabel Y (Kinerja karyawan) terhadap 58 responden, didapatkan bahwa semua butir pernyataan dinyatakan valid. Hal ini ditunjukkan dengan nilai Corrected Item-Total Correlation yang lebih besar dari 0,30, sehingga dapat dilakukan untuk penelitian lebih lanjut.

\section{Uji Reliabilitas}

Hasil Uji Reliabilitas

\begin{tabular}{clcc}
\hline No & Variabel & Cronbach's Alpha & Reliabilitas \\
\hline 1. & Disiplin Kerja & 0,699 & Reliabel \\
2. & Motivasi Kerja & 0,655 & Reliabel \\
3. & Kinerja Karyawan & 0,854 & Reliabel \\
\hline
\end{tabular}

Sumber : Data SPSS 16 (Data diolah tahun 2018)

Dari hasil uji reliabilitas, lebih dari 0,60 yang memberikan hasil dihasilkan nilai Cronbach's Alpha untuk bahwa variabel yang diteliti dapat variabel penelitian Disiplin Kerja, dikatakan reliabel.

Motivasi Kerja, dan Kinerja karyawan 


\section{Uji TCR}

Deskripsi Variabel Disiplin Kerja (X1)

Uji TCR Variabel Disiplin Kerja (X1)

\begin{tabular}{|c|c|c|c|c|}
\hline No. & $\begin{array}{c}\text { Item } \\
\text { Pernyataan }\end{array}$ & $\begin{array}{c}\text { Jumlah } \\
\text { Responden }\end{array}$ & $\underset{\%}{\text { TCR }}$ & Kriteria \\
\hline 1 & $\overline{D k} 1$ & 58 & 71 & Baik \\
\hline 2 & Dk2 & 58 & 59 & $\begin{array}{c}\text { Kurang } \\
\text { Baik }\end{array}$ \\
\hline 3 & Dk3 & 58 & 61,4 & Baik \\
\hline 4 & Dk4 & 58 & 43,8 & $\begin{array}{c}\text { Kurang } \\
\text { Baik }\end{array}$ \\
\hline 5 & Dk5 & 58 & 53 & $\begin{array}{c}\text { Kurang } \\
\text { Baik }\end{array}$ \\
\hline 6 & Dk6 & 58 & 53 & $\begin{array}{c}\text { Kurang } \\
\text { Baik }\end{array}$ \\
\hline 7 & Dk7 & 58 & 48,9 & $\begin{array}{c}\text { Kurang } \\
\text { Baik }\end{array}$ \\
\hline 8 & Dk8 & 58 & 58,5 & $\begin{array}{c}\text { Kurang } \\
\text { Baik }\end{array}$ \\
\hline \multicolumn{3}{|c|}{ Nilai rata-rata } & 56,07 & $\begin{array}{c}\text { Kurang } \\
\text { Baik }\end{array}$ \\
\hline
\end{tabular}

Sumber : Data SPSS 17 (Data diolah tahun 2018)

Dari tabel diatas maka dapat dilihat persentase paling tinggi sebesar $71 \%$ dan bahwa item pernyataan nomor empat $61,4 \%$. Kesimpulan rata-rata dari merupakan persentase paling rendah tanggapan responden terhadap variabel sebesar $43,8 \%$ dan item pernyataan disiplin kerja berada pada tingkatan nomor satu dan tiga merupakan Kurang baik, yaitu sebesar 56,07\%

Uji TCR Variabel Motivasi Kerja (X2)

\begin{tabular}{ccccl} 
No. & $\begin{array}{c}\text { Item } \\
\text { Pernyataan }\end{array}$ & $\begin{array}{c}\text { Jumlah } \\
\text { Responden }\end{array}$ & TCR \% & Kriteria \\
\hline 1 & Mk1 & 58 & 49.3 & Kurang Baik \\
2 & Mk3 & 58 & 65.6 & Baik \\
3 & Mk4 & 58 & 50.6 & Kurang Baik \\
4 & Mk5 & 58 & 54.0 & Kurang Baik \\
5 & Mk6 & 58 & 49.3 & Kurang Baik \\
6 & Mk7 & 58 & 95.7 & Sangat Baik \\
& Nilai rata-rata & 60.75 & Baik \\
\hline
\end{tabular}

Sumber : Data SPSS 17 (Data diolah tahun 2018) 
Dari tabel diatas maka dapat persentase paling tinggi sebesar 95,7\%. dilihat bahwa item pernyataan nomor Kesimpulan rata-rata dari tanggapan enam merupakan persentase paling responden terhadap variabel motivasi rendah sebesar 49,3\% dan item kerja berada pada tingkatan Baik, yaitu pernyataan nomor tujuh merupakan sebesar $60,75 \%$.

Uji TCR Variabel Kinerja Karyawan (Y)

\begin{tabular}{lllll}
\hline No. & $\begin{array}{l}\text { Item } \\
\text { Pernyataan }\end{array}$ & $\begin{array}{l}\text { Jumlah } \\
\text { Responden }\end{array}$ & $\begin{array}{l}\text { TCR } \\
\text { \% }\end{array}$ & Kriteria \\
\hline 1 & kk1 & 58 & 53.7 & Kurang Baik \\
2 & kk2 & 58 & 53.7 & Kurang Baik \\
3 & kk3 & 58 & 48.8 & Kurang Baik \\
4 & kk4 & 58 & 78.4 & Baik \\
5 & kk5 & 58 & 48.9 & Kurang Baik \\
6 & kk6 & 58 & 58.3 & Kurang Baik \\
\multicolumn{2}{l}{ Nilai rata-rata } & & 57 & Kurang Baik \\
\hline
\end{tabular}

Sumber : Data SPSS 16 (Data diolah tahun 2018)

Dari tabel diatas maka dapat dilihat bahwa item pernyataan nomor tiga merupakan persentase paling rendah sebesar $48,8 \%$ dan item pernyataan nomor empat merupakan persentase paling tinggi sebesar $78,4 \%$. Kesimpulan rata-rata dari tanggapan responden terhadap variabel motivasi kerja berada pada tingkatan Kurang Baik, yaitu sebesar 57\%.

Uji asumsi Klasik

Uji Normalitas

Data dikatakan berdistribusi normal apabila Asymp Sig (2-tailed) lebih besar dari level of significant yang dipakai yaitu 0,05 . 


\section{Hasil Uji Normalitas}

One-Sample Kolmogorov-Smirnov Test

\begin{tabular}{|c|c|c|}
\hline & $\begin{array}{c}\text { Unstandardized } \\
\text { Residual } \\
\end{array}$ \\
\hline $\mathrm{N}$ & & 58 \\
\hline \multirow[t]{2}{*}{ Normal Parameters ${ }^{\mathrm{a}, \mathrm{b}}$} & Mean & .0000000 \\
\hline & Std. Deviation & 2.30360485 \\
\hline \multirow{3}{*}{$\begin{array}{l}\text { Most Extren } \\
\text { Differences }\end{array}$} & Absolute & .178 \\
\hline & Positive & .129 \\
\hline & Negative & -.178 \\
\hline \multicolumn{2}{|l|}{ Kolmogorov-Smirnov Z } & 1.356 \\
\hline \multicolumn{2}{|l|}{ Asymp. Sig. (2-tailed) } & .051 \\
\hline
\end{tabular}

a. Test distribution is Normal.

b. Calculated from data.

Sumber : Data SPSS 17 (Data diolah tahun 2018)

Dengan data yang dapat dilihat berdasarkan hasil olahan data diatas bahwa nilai signifikansi sebesar $0,051>$ 0,05 , sehingga dapat ditarik kesimpulan bahwa data yang diolah berdistribusi normal.

\section{Uji Multikonearitas}

Uji ini digunakan untuk melihat ada atau tidak hubungan (korelasi) antara sesama variabel bebas. Pengujian ini dilakukan dengan menggunakan metode uji VIF (Variance Inflation Factor), dalam pengujian VIF menggunakan criteria pengujian apabila nilai VIF $<10$, maka dapat dikatakan tidak terjadi masalah multikonearitas dan nilai toleransinya > 0,1 maka tidak terjadi masalah multikonearitas.

\section{Hasil Uji Multikolinearitas}

\section{Coefficients $^{\mathrm{a}}$}

\begin{tabular}{|c|c|c|c|c|c|c|c|}
\hline \multirow{2}{*}{ Model } & \multicolumn{2}{|c|}{$\begin{array}{c}\text { Unstandardized } \\
\text { Coefficients }\end{array}$} & \multirow{2}{*}{$\begin{array}{c}\begin{array}{l}\text { Standardized } \\
\text { Coefficients }\end{array} \\
\text { Beta }\end{array}$} & & \multirow{2}{*}{ Sig. } & \multicolumn{2}{|c|}{$\begin{array}{l}\text { Collinearity } \\
\text { Statistics }\end{array}$} \\
\hline & B & $\begin{array}{l}\text { Std. } \\
\text { Error }\end{array}$ & & & & Tolerance & VIF \\
\hline (Constant) & 7.206 & 3.900 & & 1.848 & .070 & & \\
\hline $\begin{array}{l}\text { Disiplin } \\
\text { Kerja }\end{array}$ & .509 & .161 & .498 & 3.163 & .003 & .557 & 1.794 \\
\hline Motivasi & -.018 & .209 & -.014 & -.087 & .931 & .557 & 1.794 \\
\hline
\end{tabular}

a. Dependent Variable: Kinerja

Sumber : Data SPSS 17 (Data diolah tahun 2018) 
Berdasarkan uji multikonearitas bahwa menunjukkan nilai tolerance dari setiap variabel bebas $0,557>0,1$ dan nilai VIF $1,794<10$, maka kesimpulannya tidak terjadi masalah multikonearitas.

Dari grafik di atas terlihat bahwa plot menyebar secara tidak teratur atau tidak berpola sehingga dapat disimpulkan bahwa model regresi tidak Hasil Uji Heteroskedatisitas mengandung

masalah heteroskedastisitas.

\section{Uji Heteroskedastisitas}

Pengujian ini digunakan dengan menggunakan metode grafik plot. Apabila plot membentuk pola tertentu, maka terjadi masalah heteroskedatisitas, tetapi jika plot menyebar dan tidak membentuk suatu pola maka tidak terjadi masalah heteroskedatisitas.

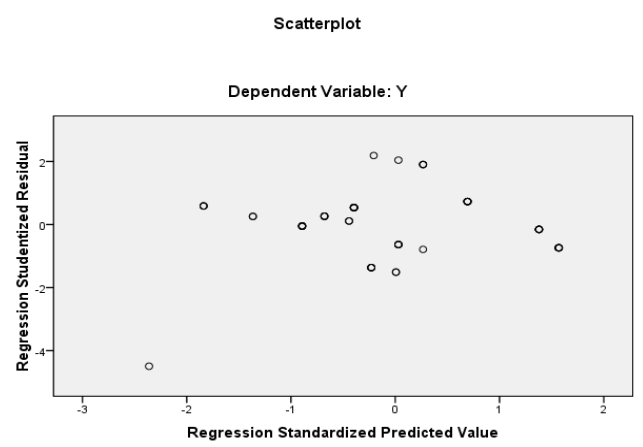

Sumber : Data SPSS 17 (Data diolah tahun 2018)

Dari grafik di atas terlihat bahwa plot menyebar secara tidak teratur atau tidak berpola sehingga dapat disimpulkan bahwa model regresi tidak mengandung heteroskedastisitas.

\section{Analisis Regresi Linear Berganda}

Analisis regresi linear berganda digunakan untuk mengukur kekuatan hubungan antara dua variabel atau lebih, dan juga menunjukkan arah hubungan antara variabel dependen dengan variabel independen. Hasil analisis regresi berganda yang diolah dengan SPSS dapat dilihat pada tabel 4.13. 


\section{Hasil Uji Regresi Linear Berganda}

Coefficients $^{\mathrm{a}}$

\begin{tabular}{|c|c|c|c|c|c|c|}
\hline & \multirow[t]{2}{*}{ Model } & \multicolumn{2}{|c|}{ Unstandardized Coefficients } & \multirow{2}{*}{$\begin{array}{c}\begin{array}{c}\text { Standardized } \\
\text { Coefficients }\end{array} \\
\text { Beta }\end{array}$} & \multirow[t]{2}{*}{$\mathrm{t}$} & \multirow[t]{2}{*}{ Sig. } \\
\hline & & B & Std. Error & & & \\
\hline \multirow{3}{*}{1} & (Constant) & 7.206 & 3.900 & & 1.848 & .070 \\
\hline & $\begin{array}{l}\text { Disiplin } \\
\text { Kerja }\end{array}$ & .509 & .161 & .498 & 3.163 & .003 \\
\hline & Motivasi & -.018 & .209 & -.014 & -.087 & .931 \\
\hline \multirow[b]{2}{*}{2} & (Constant) & 7.219 & 3.863 & & 1.869 & .067 \\
\hline & $\begin{array}{l}\text { Disiplin } \\
\text { Kerja }\end{array}$ & .500 & .119 & .489 & 4.197 & .000 \\
\hline
\end{tabular}

a. Dependent Variable: Kinerja

Sumber : Data SPSS 17 (Data diolah tahun 2018)

Berdasarkan hasil regresi yang didapat maka dibuat persamaan linear berganda sebagai berikut :

$\mathrm{Y}=7,206+0,509(\mathrm{X} 1)+(-0.18)(\mathrm{X} 2)$

Persamaan regresi linear berganda diatas mempunyai arti sebagai berikut:

1. Didalam persamaan regresi terlihat bahwa nilai konstanta yang dihasilkan bernilai sebesar 7,206. Nilai koefisien tersebut menunjukkan bahwa ketika variabel Disiplin Kerja dan Motivasi Kerja tidak mengalami perubahan atau bernilai konstan maka perubahan variabel dependen adalah sebesar konstanta yaitu 7,206. Hasil tersebut menunjukkan bahwa variabel Disiplin Kerja dan Motivasi Kerja akan berpengaruh positif terhadap Kinerja karyawan.

2. Pada koefisien regresi, variabel disiplin kerja mempengaruhi kinerja karyawan sebesar 0,509 atau berpengaruh positif terhadap kinerja karyawan, yang artinya jika variabel disiplin kerja ditingkatkan sebesar 1 satuan maka kinerja karyawan mengalami peningkatan sebesar 0,509 . Sebaliknya jika variabel motivasi kerja diturunkan sebesar 1 satuan maka keunggulan bersaing mengalami penurunan sebesar 0,509. Dengan mengasumsikan variabel lain konstan. Dengan mengasumsikan variabel lain konstan.

3. Variabel motivasi kerja tidak mempengaruhi kinerja karyawan sebesar $-0,18$ atau berpengaruh negatif terhadap kinerja karywan, yang artinya jika variabel kinerja karyawan ditingkatkan 1 satuan maka kinerja karywan mengalami peningkatan sebesar $-0,18$. Sebaliknya jika variabel motivasi kerja diturunkan sebesar 1 satuan maka kinerja karyawan mengalami penurunan sebesar $-0,18$. Dengan mengasumsikan variabel lain konstan. 


\begin{tabular}{|c|c|c|c|c|c|c|}
\hline \multicolumn{7}{|c|}{$\begin{array}{l}\text { Uji Hipotesis } \\
\text { Hasil Uji F } \\
\text { ANOVA }^{\mathbf{c}} \\
\end{array}$} \\
\hline & Model & $\begin{array}{l}\text { Sum of } \\
\text { Squares }\end{array}$ & $\mathrm{df}$ & Mean Square & $\mathrm{F}$ & Sig. \\
\hline & Regression & 95.179 & 2 & 47.590 & 8.653 & $.001^{\mathrm{a}}$ \\
\hline \multirow[t]{3}{*}{1} & Residual & 302.476 & 55 & 5.500 & & \\
\hline & Total & 397.655 & 57 & & & \\
\hline & Regression & 95.138 & 1 & 95.138 & 17.611 & $.000^{\mathrm{b}}$ \\
\hline \multirow{2}{*}{2} & Residual & 302.517 & 56 & 5.402 & & \\
\hline & Total & 397.655 & 57 & & & \\
\hline
\end{tabular}

a. Predictors: (Constant), Motivasi, DisiplinKerja

b. Predictors: (Constant), DisiplinKerja

c. Dependent Variable: Kinerja

Sumber : Data SPSS 17 (Data diolah tahun 2018

Dari tabel 4.14 diketahui hasil uji $\mathrm{f}$ terhadap kinerja karyawan, sehingga sebesar 8,653 dan nilai signifikan hipotesis yang menyatakan bahwa sebesar 0,05 . Hal ini berarti nilai disiplin kerja dan motivasi kerja secara signifikan $\mathrm{f}$ lebih kecil dari 0,05 ini bersama-sama berpengaruh terhadap menunjukkan ada pengaruh signifikan kinerja karyawan dapat diterima. antara disiplin kerja dan motivasi kerja

Coefficients $^{\mathrm{a}}$

\section{Hasil Uji T}

\begin{tabular}{|c|c|c|c|c|c|c|}
\hline \multirow{2}{*}{\multicolumn{2}{|c|}{ Model }} & \multicolumn{2}{|c|}{$\begin{array}{l}\text { Unstandardized } \\
\text { Coefficients }\end{array}$} & \multirow{2}{*}{$\begin{array}{c}\text { Standardized } \\
\text { Coefficients }\end{array}$} & \multirow[t]{2}{*}{$\mathrm{t}$} & \multirow[t]{2}{*}{ Sig. } \\
\hline & & B & Std. Error & & & \\
\hline \multirow{4}{*}{1} & (Constant) & 7.206 & 3.900 & & 1.848 & .070 \\
\hline & $\begin{array}{l}\text { Disiplin } \\
\text { Kerja }\end{array}$ & .509 & .161 & 498 & 3.163 & .003 \\
\hline & Motivasi & -.018 & 209 & -.014 & -.087 & .931 \\
\hline & (Constant) & 7.219 & 3.863 & & 1.869 & .067 \\
\hline 2 & $\begin{array}{l}\text { Disiplin } \\
\text { Kerja }\end{array}$ & .500 & 119 & 489 & 4.197 & .000 \\
\hline \multicolumn{7}{|c|}{ Dependent Variable: Kinerja } \\
\hline
\end{tabular}

Sumber : Data SPSS 17 (Data diolah tahun 2018)

Berdasarkan hasil uji t pada tabel 4.15 dapat dilkakukan analisa sebagai berikut

1. Jika nilai sig $<0,05$ atau $t$ hitung (3.163) > t table (1.6772) maka terdapat pengaruh variabel $\mathrm{X}$ terhadap Y

2. Jika nilai sig $>0,05$ atau t hitung ($0.87)<\mathrm{t}$ tabel (1.6772) maka tidak 
terdapat pengaruh variabel $\mathrm{X}$ terhadap variabel $\mathrm{Y}$

Uji Koefisien Determinasi $\left(\mathbf{R}^{2)}\right.$

\section{Hasil Uji Koefisien Determinasi $\left(\mathbf{R}^{2}\right)$}

odel Summary

\begin{tabular}{lllll}
\hline Model & $\mathrm{R}$ & R Square & Adjusted R Square & $\begin{array}{l}\text { Std. Error of } \\
\text { the Estimate }\end{array}$ \\
\hline 1 & $.536^{\mathrm{a}}$ & .287 & .261 & 1.49581
\end{tabular}

a. Predictors: (Constant), Motivasi, DisiplinKerja

Sumber: Data SPSS 17 (Data diolah tahun 2018)

Besarnya koefisien determinasi dapat dilihat pada Adjusted $R$ Square adalah sebesar 0,261 , yang mempunyai arti bahwa kinerja karyawan dijelaskan oleh variabel disiplin kerja dan motivasi kerja sebesar $26,1 \%$ dan sisanya dipengaruihi oleh faktor lain sebanyak $73.1 \%$ yang tidak diteliti, misalnya faktor pengalaman kerja kerja.

Pembahasan

Pengaruh Disiplin Kerja Terhadap Kinerja karyawan pada PT. Permodalan Nasional Madani (Persero) Cab. Padang

Berdasarkan hasil pengujian hipotesis pertama, ditemukan bahwa variabel disiplin kerja berpengaruh positif dan signifikan terhadap motivasi kerja pada PT.PNM Cabang Padang. Besaran koefisien regresi variabel disiplin kerja 0,261 dan signifikansinya sebesar 0,003 yang lebih kecil dari 0,05. Hal ini dapat diartikan bahwa variabel disiplin kerja berpengaruh positif dan signifikan terhadap kinerja karyawan, dengan demikian, hipotesis pertama (H1) dalam penelitian ini yang menyatakan bahwa disiplin kerja berpengaruh positif dan signifikan terhadap kinerja karyawan pada PT.PNM Cabang Padang, dinyatakan dapat diterima.

Hal ini berarti bahwa disiplin kerja bertambah akan menyebabkan meningkatnya kinerja karyawan pada

PT.PNM Cabang Padang, hal tersebut mengembangkan pernyataan Robbins dan Judge (2006) bahwa disiplin kerja dapat mempengaruhi emosi, proses berpikir, dan kondisi fisik dan mental seseorang.

Pengaruh Motivasi kerja Terhadap Kinerja karyawan pada PT.PNM Cabang Padang

Berdasarkan hasil pengujian hipotesis kedua, ditemukan bahwa variabel motivasi kerja berpengaruh negatif dan tidak signifikan terhadap kinerja karyawan pada PT.PNM Cabang Padang. Besaran koefisien regresi variabel motivasi kerja $-0,18$ dan signifikansinya sebesar 0,931 yang lebih besar dari 0,05 . Hal ini dapat diartikan bahwa variabel motivasi kerja berpengaruh negatif dan tidak signifikan terhadap kinerja karyawan, dengan demikian, hipotesis kedua (H2) dalam penelitian ini yang menyatakan bahwa motivasi kerja berpengaruh negatif dan tidak signifikan terhadap kinerja karyawan pada PT.PNM Cabang Padang, dinyatakan ditolak.

Hal ini bermakna jika motivasi kerja rendah, maka kinerja karyawan akan tetap terjadi pada PT.PNM Cabang Padang. 


\section{KESIMPULAN DAN SARAN Kesimpulan}

Berdasarkan hasil penelitian yang telah dilakakuan di PT.PNM Cabang Padang dan hasil pembahasannya, maka pada bab ini penulis dapat menarik beberapa kesimpulan sebagai berikut :

1. Berdasarkan hasil penelitan yang dilakukan, menunjukkan bahwa disiplin kerja berpengaruh positif dan signifikan terhadap kinerja karyawan pada PT.PNM Cabang Padang. Ini dapat dilihat dari Uji Linear Berganda dimana nilai signifikannya sebesar $0,003(0,003<$ 0,05 : signifikan) dan nilai koefisien regresinya sebsesar 0,509 yang artinya bahwa apabila disiplin kerja maka semakin bertambah akan menyebabkan meningkatnya kinerja karyawan pada PT.PNM Cabang Padang.

2. Berdasarkan hasil penelitan yang dilakukan, menunjukkan motivasi kerja berpengaruh negatif dan tidak signifikan terhadap kinerja karyawan pada PT.PNM Cabang Padang. Ini dapat dilihat dari Uji Linear Berganda dimana nilai signifikannya sebesar $0,931(0,931>$ 0,05 : tidak signifikan) dan nilai koefisien regresinya sebesar $(-0,18)$ yang artinya apabila motivasi kerja rendah pada organisasi tersebut, maka kinerja karyawan tetap akan terjadi pada PT.PNM Cabang Padang.

3. Dari hasil uji koefisien determinasi $\left(\mathrm{R}^{2}\right)$ di atas dapat terlihat pada Adjusted $R$ Square sebesar 0,261 yang mempunyai arti bahwa variabel kinerja karyawan (Y) dipengaruhi oleh variabel disiplin kerjaa (X1) dan motivasi kerja (X2) sebesar $26,1 \%$. Sedangkan sisanya
73,9\% kinerja karyawan dipengaruhi oleh variabel-variabel lainnya yang tidak diteliti dalam penelitian ini, contohnya variable pengalaman kerja.

\section{UCAPAN TERIMAKASIH}

Dalam penyusunan penelitian ini, penulis menyadari bahwa tanpa bimbingan dan bantuanberbagai pihak, penulis belum tentu menyelesaikan penelitian ini. Untuk itu ucapan terimakasih yang sebesar- besarnya penulis sampaikan kepada Bapak Febryandhie Ananda, SE, M.Si, selaku Ketua di STIE "KBP" Padang yang telah memberikan bimbingan dan fasilitas selama penulis menjadi mahasiswa. Ibu Lidya Martha, SE, MM selaku wakil ketua di STIE "KBP” Padang. Ibu Febsri Susanti, SEI, MM selaku Ketua Program Studi Manajemen STIE “KBP” Padang. Ibu Maria Magdalena, S.Pd, MM, selaku Dosen Pembimbing Skripsi yang dengan sabar sabar memberikan bimbingan dalam penyelesaian skripsi ini.

\section{DAFTAR PUSTAKA}

Almilia, S. L., \& Herdinigtyas, W. (2005). Analisis Rasio Camel Terhadap Prediksi Kondisi Bermasalah Pada Lembaga Perbankan Perioda 2000-2002. Jurnal Akuntansi Dan Keuangan, 7(2), 131-147.

https://doi.org/10.9744/jak.7.2.pp. 131-147

Anggraeni. (2013). Pengaruh Kepemimpinan Transformasional terhadap Kepuasan Kerja Karyawan. Jurnal Dinamika Ekonomi \& Bisnis, 10(1), 51-68. https://doi.org/10.7498/aps.63.0942 06 
Dona, E. (2016). Pengaruh Perencanaan, Prosedur Dan Pengawasan dan Komitmen Organisasi Dalam Pelaksanaan Anggaran Terhadap Kinerja Pegawai Dinas Pekerjaan Umum Kota Pariaman. Jurnal Riset Manajemen dan Akuntansi (Jurmak), 23-35.

Dona, E. (2018). Analisis Motivasi Kerja Ditinjau Dari Lingkungan Kerja Kasus Karyawan LBPP Lia Payakumbuh. Jurnal KBP.

Ghezanda, R., Sunuharyo, B. S., Susilo, H., Administrasi, F. I., \& Kerja, K. S. (2001). Pengaruh karakteristik individu dan karakteristik situasi kerja terhadap motivasi kerja karyawan.

Giovanni, M., Kojo, C., \& Lengkong, V. P. . (2015). Pengaruh Konflik Peran, Konflik Kerja dan Stres Kerja Terhadap Kinerja Karyawan Pada PT. Air Manado. Jurnal EMBA, 3(3 September 2015), 9098.

Hakim, M. L., \& Arum Darmawati, S.E, M. M. (2015). Pengaruh Stres Kerja dan Kesempatan Promosi Terhadap Turnover Intention. Jurnal Manajemen, 95.

Hidayat, Z., \& Taufiq, M. (2012). Pengaruh Lingkungan Kerja dan Disiplin Kerja serta Motivasi Kerja Terhadap Kinerja Karyawan Perusahaan Daerah Air Minum ( PDAM ) Kabupaten Lumajang, 2(1), 79-97.

Kharismawan, T. (2010). Pengaruh Gaya Kepemimpinan Terhadap Motivasi Kerja Karyawan Pada Pt Pos Indonesia (Persero). Pengaruh Gaya Kepemimpinan Terhadap Motivasi Kerja Karyawan Pada Pt Pos Indonesia (Persero).

Khasanah, Nur. (2010). Disiplin Kerja
Pegawai Bagian Langganan Pdam Surakarta Tugas. Disiplin Kerja Pegawai Bagian Langganan Pdam Surakarta Tugas.

Marlius, D. RD Putra. (2018). Strategi Pengembangan Sulam Bayang. Jurnal Benefita: Ekonomi Pembangunan Manajemen Bisnis Dan Akuntansi. Volume 3. No. 2. Hal. 204-218. http://doi.org/10.22216/jbe.v3i2.34 94

Manajemen, J., Universitas, P., Kuala, S., Kurniawan, D., Lubis, A. R., \& Adam, M. (2012). Terhadap Kinerja Karyawan International Federation Red Cross ( Ifrc ), 1(1), 1-15.

Mayliza, R. (2019). Pengaruh Gaya Kepemimpinan Dan Disiplin Kerja Terhadap Kinerja Karyawan Dengan Motivasi Kerja Sebagai Variabel Intervening Pada PT. Semen Padang. https://doi.org/10.17605/OSF.IO/F YPQ9.

Mayliza, R. (2019). Pengaruh Konflik Dan Kejenuhan Terhadap Kepuasan Kerja Karyawan PT. PLN (Persero) Sektor Pembangkitan Dan Pengendalian Pembangkitan Ombilin. https://doi.org/10.17605/OSF.IO/D QZ3K

Mayliza, R. (2019). Kontribusi Sistem Penghargaan Dan Lingkungan Kerja Terhadap Efektifitas Kerja Pegawai Pada Kantor Dinas Pendidikan Kota Padang. https://doi.org/10.17605/OSF.IO/V WZH3

Mayliza, R. (2019). Pengaruh Gaya Kepemimpinan Dan Disiplin Kerja Terhadap Kinerja Pegawai, Dengan Motivasi Kerja Sebagai Variabel Intervening (Studi Pada Dinas 
Pendidikan Kabupaten Tanah Datar).

https://doi.org/10.17605/OSF.IO/JG PDN

Nardo, R. Evanita, Syahrizal, S. (2018). Pengaruh Kepemimpinan Transformasional, Dan Lingkungan Kerja Non Fisik Terhadap Perilaku Inovatif. JEBI (Jurnal Ekonomi dan Bisnis Islam) 3 (2), 209-215

Nardo, R. Evanita, Syahrizal, S. (2019). The Effect of Transformational Leadership and Non Physical Work Environment on Innovative Behavior with Work Motivation as a Mediation For Employees of Tour And Travel Companies In West Sumatera. 2nd Padang International Conference on Education, Economics, Business and Accounting (PICEEBA-2 2018)

Pima Rahmawanti Bambang Swasto Arik Prasetya, N., Kunci, K., Kerja Fisik, L., Kerja Non Fisik, L., \& Karyawan, K. (2014). PENGARUH LINGKUNGAN TERHADAP KERJA KARYAWAN (Studi pada Karyawan Kantor Pelayanan Pajak Pratama Malang Utara). Jurnal Administrasi Bisnis, 8(2), 1-9. Retrieved from http://administrasibisnis.studentjour nal.ub.ac.id/index.php/jab/article/vi ew/366/561

Prihantoro, A. (2012). Peningkatan Kinerja Sumber Daya Manusia Melalui Motivasi, Disiplin, Lingkungan Kerja, Dan Komitmen. Jurnal Value Added, 8(2), 78-98.

Putra, RY. Marlius, D. (2019). Pengaruh Pendidikan, Pengalaman Kerja dan Etos Kerja Terhadap Kinerja Pegawai Di KPN Batur. Academic Conference For Management 2.
Rahmizal, M. (2018). Pengaruh Pendapatan, Pendidikan, Kesehatan, Modal Sosial Dan Religiusitas Terhadap Kebahagiaan Individu Di Indonesia. Universitas Gadjah Mada

Rahmizal, M. (2017). Analysis of Indonesia Marine Fisheries with Economic Growth, Population and Effort Effectiveness. European Journal of Engineering and Formal Sciences 1 (1), 17-22

Ramli, K. (2013). Pengaruh persepsi gaya kepemimpinan transformasional terhadap disiplin kerja karyawan di pt borneo alam semesta, desa adong, melak, kutai barat, kalimantan timur. E-Jurnal Untag, 1(1), 1-28. Retrieved from http://ejurnal.untag-

Smd.Ac.Id/Index.Php/MTV/Article/ View/301/437

Sanjaya, M. T. R. (2015). Pengaruh Disiplin dan Motivasi Kerja Terhadap Kinerja Karyawan Pada Hotel Ros In Yogyakarta.

Santoso, E. (2006). Pengaruh Kepemimpinan,Motivasi,

Kompensasi Dan Disiplinkerja Terhadap Kinerja Karyawan. Pengaruh Kepemimpinan,Motivasi, Kompensasi Dan Disiplinkerja Terhadap Kinerja Karyawan.

SARI, P. M. (2015). I Pengaruh Pengawasan Kerja Dan Disiplin Kerja Terhadap Kinerja Karyawan Pada Pt. Djitoe Indonesian Tobacco Di Surakarta.

Sarita, J., \& Agustia, D. (2009). Pengaruh Gaya Kepemimpinan Situasional, Motivasi Kerja, Locus Control terhadap Kepuasan Kerja dan Prestasi Kerja Auditor. Simposium Nasional Akuntansi XII, 1-29.

Setiawan, A. (2013). Pengaruh Disiplin 
Kerja Dan Motivasi Terhadap Kinerja Karyawan Pada Rumah Sakit Umum Daerah Kanjuruhan Malang Agung. Ilmu Manajemen, l(4), 1247.

Susilo, T. (2000). Analisis Pengaruh Faktor Lingkungan Fisik Dan Non Fisik Terhadap Stress Kerja Pada Pt. Indo Bali Di Kecamatan Negara, Kabupaten Jimbaran, Bali.

Susriyanti, S. Nardo, R. (2019).

Pengaruh Fungsi Komunikasi Dan Kepuasan Kerja Karyawan Terhadap Pemberian Pelayanan Nasabah PT. BPR LPN Talawi Sakato. Jurnal Administrasi Sosial dan Humaniora 3 (2), 97-111.

Tri, O., Staff, W., Stie, P., \& Salatiga, A. (2010). Pengaruh Lingkungan Kerja, Budaya Organisasi, Kepemimpinan Terhadap Kinerja (Studi pada Pegawai Kecamatan Sidorejo Kota Salatiga). Among Makarti, 3(5), 14-35.

Usrin, I., Mutiara, E., \& Yusad, Y. (2012). 1 , 2 , 2. Pengaruh Hipertensi Terhadap Kejadian Stroke Iskemik Dan Stroke Hemoragik Di Ruang Neurologi Di Rumah Sakit Stroke Nasional (Rssn) Bukittinggi Tahun 2011, 19.https://doi.org/10.1002/ejic.201402 692

Yudistira, D. S., \& Susanti, F. (2019). Pengaruh Motivasi Kerja Dan Budaya Kerja Terhadap Kinerja Karyawan Dinas Pemberdayaan Masyarakat Dan Desa, Pengendalian Penduduk Dan Keluarga Berencana
Kabupaten Pesisir Selatan. https://doi.org/10.31227/osf.io/jk54m Ridho, M., \& Susanti, F. (2019). Pengaruh Stres Kerja Dan Motivasi Kerja Terhadap Kepuasan Kerja Pada Karyawan Bank Mandiri Syariah Cabang Padang. https://doi.org/10.31227/osf.io/pa2cg

Lubis, A. Y. O., \& Susanti, F. (2019). Pengaruh Gaya Kepemimpinan Dan Kompensasi Terhadap Prestasi Kerja Karyawan (Studi pada PT Japfa Comfeed Indonesia (JCI) Tbk Devisi Fam 1. https://doi.org/10.31227/osf.io/7tbrg

Jamarnis, S., \& Susanti, F. (2019). Pengaruh Harga Dan Periklanan Melalui Internet Terhadap Keputusan Pembelian Produk Sabun Merek Lux Pada Mahasiswa STIE "KBP" Padang. https://doi.org/10.31227/osf.io/xz3d8 Aldi, Y., \& Susanti, F. (2019). Pengaruh Stress Kerja Dan Motivasi Kerja Terhadap Prestasi Kerja Karyawan Pada PT. Frisian Flag Indonesia Wilayah Padang. https://doi.org/10.31227/osf.io/et4rn

Junaidi, R., \& Susanti, F. (2019). Pengaruh Gaya Kepemimpinan Dan Budaya Organisasi Terhadap Kinerja Pegawai Pada UPTD Baltekkomdik Dinas Pendidikan Provinsi Sumatera Barat. https://doi.org/10.31227/osf.io/bzq75 